\title{
PENYESUAIAN MAHASISWA TAHUN PERTAMA DI PERGURUAN TINGGI: STUDI PADA MAHASISWA FAKULTAS PSIKOLOGI UKSW
}

\author{
Maria Nugraheni Mardi Rahayu, Rudangta Arianti \\ Fakultas Psikologi, Universitas Kristen Satya Wacana \\ Jl. Diponegoro No. 52-60, Salatiga \\ E-mail:nugraheni.maria@uksw.edu
}

\begin{abstract}
ABSTRAK
Transisi dari SMA ke universitas menimbulkan berbagai tantangan bagi mahasiswa tahun pertama yang memasuki masa dewasa awal. Namun, sebagian mahasiswa ada yang mengalami kesulitan dan membutuhkan bantuan dalam melakukan penyesuaian. Penelitian deskriptif ini bertujuan untuk mengetahui gambaran penyesuaian mahasiswa tahun pertama di perguruan tinggi ditinjau dari jenis kelamin, asal daerah, dan tempat tinggal mahasiswa. Sebanyak 227 mahasiswa tahun pertama di Fakultas Psikologi UKSW menjadi partisipan dalam penelitian ini. Penelitian ini menggunakan adaptasi bahasa Indonesia dari kuesioner SACQ dari Baker dan Siryk (1984) yang terdiri dari 4 subskala yaitu penyesuaian akademik, penyesuaian sosial, penyesuaian personal-emosional, dan kelekatan institusional. Hasil penelitian menunjukkan bahwa sebagian besar mahasiswa tahun pertama telah memiliki tingkat penyesuaian di perguruan tinggi yang tergolong sedang dan tinggi di seluruh subskala. Di sisi lain, masih terdapat sebagian mahasiswa yang memiliki tingkat penyesuaian yang tergolong rendah yaitu sebanyak 14,98\% pada subskala penyesuaian akademik, 9,69\% pada subskala penyesuaian sosial, 15,42\% pada subskala penyesuaian personal-emosional, dan 19,38\% pada subskala kelekatan institusional. Hasil analisis uji beda menunjukkan bahwa terdapat perbedaan signifikan pada subskala penyesuaian akademik dan kelekatan institusional ditinjau dari daerah asal mahasiswa, subskala penyesuaian personal-emosional ketika ditinjau dari jenis kelamin, dan subskala kelekatan institusional ditinjau dari tempat tinggal mahasiswa. Temuan ini mengindikasikan bahwa universitas dan fakultas perlu menyediakan program penyesuaian mahasiswa yang dapat meningkatkan kelekatan mahasiswa terhadap institusi tanpa mengesampingkan kegiatan yang dapat meningkatkan penyesuaian akademik, sosial dan personal-emosional.
\end{abstract}

Kata kunci: penyesuaian mahasiswa; mahasiswa tahun pertama; jenis kelamin; asal daerah mahasiswa; tempat tinggal mahasiswa.

\section{FRESHMEN ADJUSTMENT: A STUDY ON STUDENTS AT FACULTY OF PSYCHOLOGY SWCU}

\begin{abstract}
The transition from high school to college poses various challenges for freshmen who are in the phase of emerging adulthood. However, there are still some students who experience difficulties and require some help to adjust. This study aims to describe the adjustment of freshmen in college and how different is the level of adjustment in college in terms of gender, the region of origin, and student's residence. A total of 227 freshmen at the SWCU Psychology Faculty participated in this study. This study uses Indonesian adapted version of SACQ from Baker and Siryk (1984) consisting of four subscales, namely academic adjustment, social adjustment, personal-emotional adjustment, and institutional attachment. Results show that most students already have a moderately high level of adjustment to college across all four subscales. However, there are still some students who score relatively low on other subscales of adjustment: academic (14.98\%), social (9.69\%), personal-emotional (15.42\%), and institutional attachment subscale (19.38\%). The comparative statistical test shows that differences of region of origins, students' gender, and type of student's residences are the significant factors which distinguish those subscales' score, respectively. The findings indicate that university and faculty must design student adjustment programs that can increase student's institutional attachment without setting aside activities that can improve academic, social, and personal emotional adjustment.
\end{abstract}

Keyword: student adjustment to college; first-year students; gender; student's region of origin; student's residence. 


\section{PENDAHULUAN}

Penyesuaian (adjustment) merupakan proses yang tidak pernah lepas dari kehidupan manusia, terutama saat menghadapi perubahan. Demikian pula halnya dengan mahasiswa baru saat memasuki lingkungan perguruan tinggi setelah lulus dari SMA. Proses ini biasanya dialami individu saat berusia 18-25 tahun, yang merupakan periode di mana individu merasa tidak lagi termasuk remaja, tapi juga belum sepenuhnya dewasa, yang sering disebut sebagai tahap emerging adulthood (Arnett, 2000). Periode tahun pertama perkuliahan sering dianggap sebagai masa yang paling menantang bagi mahasiswa (Feldt et al., 2011), di mana pada masa ini mahasiswa akan menemui berbagai situasi yang baru seperti sistem perkuliahan, metode pembelajaran yang berbeda dengan SMA, materi perkuliahan yang lebih sulit, teman-teman yang berasal dari daerah yang berbeda, maupun lingkungan tempat tinggal yang baru. Sistem pendidikan di universitas dapat menjadi hal yang membingungkan bagi mahasiswa baru dan kebingungan ini menjadi lebih besar ketika mahasiswa datang dari berbagai bahasa dan latar belakang budaya yang beragam (Cooper, 2009, dalam Bibi et al., 2018).Perubahan lingkungan yang mesti dihadapi oleh mahasiswa baru di perguruan tinggi ini akan membentuk persepsi mereka, terutama mengenai kemampuannya untuk dapat mengatasi berbagai hambatan dan tantangan dalam kehidupan universitas mereka (Siah \& Tan, 2015; Wider et al., 2017). Ketika mahasiswa baru tidak dapat mengatasi berbagai tantangan dan hambatan ini, hal tersebut dapat mengarah pada berbagai masalah di kemudian hari, terutama masalah psikologis. Untuk dapat menghadapi berbagai tantangan dan masalah saat memasuki perguruan tinggi, mahasiswa perlu memiliki kemampuan untuk menyesuaikan diri dengan lingkungan di sekitarnya.

Penyesuaian (adjustment) merujuk pada harmoni antara individu dengan dirinya sendiri dan elemen lain di sekitarnya (Brady-Amoon \& Fuertes, 2011, dalam Parmaksiz, 2019). Secara lebih spesifik, Anderson et al. (2016) mendefinisikan penyesuaian akademik mahasiswa di perguruan tinggi sebagai kemampuan individu untuk mengelola tantangan sosial, psikologis, dan keilmuan ketika mengalami transisi ke kehidupan perkuliahan. Proses penyesuaian ini merupakan cara di mana individu berusaha untuk mengatasi stres, konflik, ketegangan dan memenuhi kebutuhan mereka (Mutambara \& Bhebe, 2012). Dengan kata lain, penyesuaian ini dapat kita lihat sebagai kondisi atau keadaan di mana mahasiswa merasa bahwa kebutuhan mereka telah terpenuhi dan bahwa perilaku mereka telah sesuai dengan kebutuhan dari lingkungan (Salami, 2011). Baker dan Siryk (1984) menggunakan pendekatan multifaset dalam menjelaskan penyesuaian pada mahasiswa di perguruan tinggi. Lebih lanjut, Baker dan Siryk (1984) memaparkan bahwa penyesuaian mahasiswa di perguruan tinggi ini terdiri dari 4 subskala yaitu penyesuaian akademik (academic adjustment), penyesuaian sosial (social adjustment), penyesuaian personal-emosional (personal-emotional adjustment), dan kelekatan institusi (institutional attachment).

Subskala penyesuaian akademik merujuk pada motivasi mahasiswa untuk tetap berada di universitas dan mengerjakan tugas-tugas kuliah, menerjemahkan motivasi ke dalam usaha akademik yang nyata, keyakinan dan keberhasilan atas usaha yang dilakukan, dan kepuasan mahasiswa terhadap lingkungan akademis (Baker, 2002). Subskala ini dirancang untuk mengukur bagaimana respons mahasiswa terhadap tuntutan akademik di perguruan tinggi (Gold et al., 1990). Mahasiswa dengan tingkat penyesuaian akademik yang tinggi artinya mahasiswa menilai bahwa respons mental maupun perilaku mereka sudah efektif untuk menjawab tuntutan akademik yang diharapkan di lingkungan perguruan tinggi dan jurusan yang mereka tekuni sekarang. Skor yang rendah pada subskala penyesuaian akademik menunjukkan asosiasi dengan tingkat IPK yang lebih rendah, penerimaan sementara ke perguruan tinggi karena IPK sekolah menengah rendah, berada dalam masa percobaan akademis dan perasaan kurangnya kontrol oleh siswa mengenai hasil pendidikan (Baker \& Siryk, 1989 dalam Gold et al., 1990).

Subskala penyesuaian sosial merujuk pada tingkat dan keberhasilan mahasiswa dalam aktivitas sosial dan keberfungsian secara umum, keterlibatan dengan orang lain di kampus, relokasi dari daerah asal dan orang-orang signifikan yang ada di sana, serta kepuasan mahasiswa terhadap lingkungan sosial di universitas. Subskala ini mengukur bagaimana respons mahasiswa terhadap tuntutan interpersonal/sosial di lingkungan universitas (Gold et al., 1990). Mahasiswa dengan tingkat penyesuaian sosial yang tinggi artinya mahasiswa menilai bahwa respons mental dan perilaku mereka telah sesuai dengan tuntutan lingkungan dalam hal interpersonal dan sosial di lingkungan perguruan tinggi dan tempat tinggal mereka saat ini. Skor yang rendah pada subskala ini memiliki kaitan dengan kurangnya partisipasi dalam kegiatan sosial perguruan tinggi, kurang sukses dalam proses tinggal sendiri, rasa kesepian yang lebih besar, keberhasilan dalam mengatasi perubahan kehidupan lebih sedikit dan kurang percaya diri sosial (Baker \& Siryk, 1989, dalam Gold et al., 1990).

Subskala penyesuaian personal-emosional mengarah pada tingkat kesejahteraan psikologis dan fisik yang dirasakan oleh mahasiswa. Dimensi ini berfokus pada kondisi psikologis yang dialami mahasiswa secara umum serta gejala-gejala somatik yang muncul dalam proses 
penyesuaian mahasiswa di perguruan tinggi. Subskala ini mengukur tingkat distres psikologis dan fisik yang dialami mahasiswa (Gold et al., 1990). Mahasiswa yang memiliki tingkat penyesuaian personal-emosional yang tinggi berarti mahasiswa menilai bahwa mereka memiliki kesejahteraan psikologis serta kondisi fisiologis yang baik selama menjalani proses penyesuaian diri di lingkungan perguruan tinggi. Baker dan Siryk (1989, dalam Gold et al., 1990) menjelaskan bahwa skor yang lebih rendah pada subskala ini mencerminkan ketergantungan emosional yang lebih besar pada orang lain, sumber daya psikologis yang lebih sedikit, tingkat kesehatan mental yang lebih rendah, dan pengalaman negatif yang lebih besar dari peristiwa kehidupan.

Subskala kelekatan institusional mengukur kepuasan mahasiswa terhadap keputusannya untuk berada di perguruan tinggi secara umum dan terhadap keputusan untuk berada di institusi pendidikan yang saat ini sedang ditempuh (Gold et al., 1990). Mahasiswa dengan tingkat kelekatan institusional tinggi artinya mahasiswa menilai bahwa mereka merasa puas saat menjalani kehidupan di perguruan tinggi yang telah dipilih serta memiliki keterikatan yang dibutuhkan dengan jurusan yang ditekuni secara khusus. Skor yang lebih rendah pada subskala ini mencerminkan kurangnya kepuasan terhadap pengalaman di universitas dan kemungkinan yang lebih besar untuk putus kuliah.

Penyesuaian di perguruan tinggi yang sukses dapat dilihat salah satunya dari keterlibatan mahasiswa dalam aktivitas di universitas, kesejahteraan psikologis mereka, dan performa akademik yang baik (Mutambara \& Bhebe, 2012). Peneliti kemudian melakukan pengumpulan data awal mengenai proses adaptasi mahasiswa baru di perguruan tinggi yaitu kepada mahasiswa angkatan 2019 dalam proses perwalian akademik. Pengumpulan data ini dilakukan selama proses perwalian pada bulan Agustus hingga Oktober 2019 dengan proses tanya jawab kepada mahasiswa mengenai penyesuaian diri mereka selama berkuliah maupun kendala yang dialami. Selain itu, peneliti juga menggunakan data dari hasil diskusi dosen pengajar dalam rapat Fakultas Psikologi UKSW pada bulan September 2019 tentang kondisi mahasiswa baru angkatan 2019. Berdasarkan hasil pengumpulan data awal ini, sebagian besar mahasiswa baru tampak telah banyak terlibat dalam berbagai aktivitas di universitas seperti kelompok bakat minat, kelompok diskusi, maupun menjadi panitia dalam berbagai kegiatan di kampus. Selain itu, sebagian mahasiswa melaporkan bahwa mereka sudah mulai merasa nyaman dan betah tinggal di Salatiga maupun belajar di UKSW. Beberapa mahasiswa juga melaporkan bahwa mereka telah memiliki teman dekat yang saling membantu dalam proses penyesuaian di universitas.

Di sisi lain, terdapat beberapa mahasiswa baru menyatakan bahwa mereka menemui kesulitan dalam proses penyesuaian mereka di perguruan tinggi. Adapun keluhan-keluhan yang disampaikan oleh mahasiswa di antaranya adalah mahasiswa merasa kurang mampu mengerjakan tugas-tugas di perkuliahan, kurang memiliki keinginan untuk mengerjakan tugas-tugas kuliah, kesulitan memahami dosen yang terkadang menggunakan istilah dalam Bahasa Jawa dan merasa malu untuk bertanya saat tidak memahami penjelasan dosen. Dalam hal interaksi dengan teman, beberapa mahasiswa mengeluhkan mereka kesulitan berkomunikasi dengan teman seangkatan karena perbedaan bahasa sehingga membuat mereka enggan untuk bekerja sama dalam tugas kelompok. Ada juga yang merasa rindu dengan daerah asal atau rumah (home sick) dan tidak betah dengan lingkungan baru, merasa kesulitan untuk berteman dengan teman-teman seangkatan atau teman di kos, merasa tidak cocok dengan makanan di lingkungan baru sehingga merasa tidak nyaman dan tidak bisa konsentrasi belajar. Kondisi lainnya adalah beberapa mahasiswa mengeluhkan bahwa selama berada di lingkungan baru, mereka mengalami gangguan kesehatan fisik seperti sakit kepala, gangguan lambung dan pencernaan, gangguan tidur, dan kelelahan, merasa stress dan tidak bahagia, tidak termotivasi belajar karena ingin berkuliah di tempat lain, merasa salah jurusan, dan tidak ingin melanjutkan studi hingga mencapai gelar S1.

Temuan ini menguatkan pandangan beberapa penelitian sebelumnya yang menunjukkan bahwa meskipun sebagian mahasiswa dapat menyesuaikan diri dengan baik di lingkungan perguruan tinggi, terdapat sebagian mahasiswa lainnya yang merasa kesulitan dengan proses transisi ini (Mutambara \& Bhebe, 2012). Masalah kesulitan penyesuaian merupakan masalah yang umum ditemui pada mahasiswa tahun pertama (Wider et al., 2016; Clinciu \& Cazan, 2013). Bagi mahasiswa tahun pertama, selain perubahan dalam kehidupan akademik, mahasiswa baru juga akan mengalami perubahan dalam kehidupan sosialnya. Keberadaan kehidupan sosial baru yang mana mahasiswa merupakan bagian baru dari institusi, dapat menjadi anggota aktif dalam komunitas di universitas, serta menyesuaikan diri mereka dengan peran dan tanggung jawab baru adalah hal yang perlu diupayakan oleh mereka sehingga dapat menyesuaikan diri dengan sukses (Sholeh et al., 2018). Periode transisi ini dapat menjadi periode yang penuh stres bagi individu yang memasuki masa dewasa awal (emerging adult), yang mana mereka mengalami transisi ganda yaitu baik secara perkembangan psikologis maupun secara institusional (Villatte et al., 2017). Masalah-masalah yang umum dihadapi mahasiswa di antaranya mahasiswa mulai tinggal terpisah dari keluarga, sulit mengatur keuangan, masalah dalam menjalin relasi dengan lawan jenis maupun teman sebaya di perkuliahan, serta di organisasi kemahasiswaan (Nurfitriana, 2016; Lidy \& Kahn, 2006; Feldt et al., 2011). Pengalaman awal mahasiswa ini dapat memengaruhi sikap dan kepercayaan diri mereka secara signifikan terhadap kemampuan mereka untuk melanjutkan pendidikan di tahun-tahun berikutnya (Dawborn-Gundlach \& Margetts, 2018).

Ketika masalah penyesuaian mahasiswa di perguruan tinggi tidak ditangani dengan tepat, hal ini dapat berdampak negatif terhadap perkembangan studi mahasiswa pada masa berikutnya. Beberapa masalah yang memiliki kaitan dengan masalah penyesuaian 
mahasiswa di tahun-tahun awal antara lain adalah stres (Saniskoro \& Akmal, 2017; Handono \& Bashori, 2013; Fuad \& Zarfiel, 2013), kurang dapat berinteraksi sosial dengan orang lain di lingkungan (Wijanarko \& Syafiq, 2013), munculnya perasaan kesepian dan homesickness (Mutambara \& Bhebe, 2012; Mariska, 2018) bahkan sebagian mahasiswa mengundurkan diri dan tidak melanjutkan kuliah pada tahun berikutnya (Mudhovozi, 2012).

Mengingat bahwa kendala dalam proses penyesuaian ini dapat memengaruhi performa dan capaian akademik mahasiswa, kesulitan mahasiswa dalam proses menyesuaikan diri di lingkungan akademik perlu dipandang sebagai masalah yang serius. Universitas dan fakultas perlu menyediakan program-program yang dapat membantu proses penyesuaian mahasiswa di perguruan tinggi sesuai dengan kebutuhan mahasiswa. Pemrograman yang strategis mungkin dapat mencegah insiden putus kuliah maupun masalah psikologis lainnya pada mahasiswa yang disebabkan oleh rendahnya penyesuaian di perguruan tinggi. Untuk dapat mengembangkan program yang dapat menjawab kebutuhan mahasiswa dalam proses penyesuaian di perguruan tinggi, tinjauan terhadap gambaran penyesuaian diri pada mahasiswa menjadi penting untuk dilakukan. Oleh karena itu, penelitian ini bertujuan untuk mengetahui bagaimana tingkat penyesuaian mahasiswa baru Fakultas Psikologi UKSW di perguruan tinggi yang ditinjau dari empat dimensi penyesuaian mahasiswa di perguruan tinggi yang dikemukakan oleh Baker dan Siryk (1984), yaitu penyesuaian akademik, penyesuaian sosial, penyesuaian personal-emosional dan kelekatan terhadap institusi. Dengan adanya hasil dari penelitian ini, diharapkan universitas dan fakultas dapat memperoleh data empiris mengenai bagaimana tingkat penyesuaian mahasiswa baru Fakultas Psikologi UKSW berdasarkan 4 domain penyesuaian mahasiswa di perguruan tinggi, sehingga dapat dirancang program pengembangan yang sesuai dengan kebutuhan mahasiswa.

Lebih lanjut, beberapa penelitian pada mahasiswa secara umum menunjukkan bahwa faktor-faktor demografis rupanya memegang peranan terhadap tinggi rendahnya penyesuaian mahasiswa di perguruan tinggi. Tinjauan terhadap perbedaan tingkat penyesuaian mahasiswa di perguruan tinggi yang berasal dari kelompok karakteristik yang berbeda sangat diperlukan untuk dapat menyusun program pengembangan mahasiswa yang tepat sasaran. Hasil dari kajian ini dapat digunakan untuk memetakan kelompok-kelompok mahasiswa yang membutuhkan bantuan dalam mengatasi masalah penyesuaian di perguruan tinggi. Oleh karena itu, penelitian ini juga akan mengkaji mengenai bagaimana perbedaan tingkat penyesuaian mahasiswa baru Fakultas Psikologi UKSW di perguruan tinggi ditinjau dari variable demografinya seperti jenis kelamin (laki-laki dan perempuan), asal tempat tinggal (mahasiswa lokal, mahasiswa pendatang dari Jawa, dan mahasiswa pendatang dari Luar Jawa), dan tempat tinggal saat ini (tinggal bersama keluarga dan tinggal sendiri di kos/asrama/kontrak dengan mahasiswa lain).

\section{METODE}

Penelitian ini bertujuan untuk mendeskripsikan tingkat penyesuaian mahasiswa pada tahun pertama yang meliputi penyesuaian akademik, personal-emosional, sosial dan kelekatan institusi. Populasi dalam penelitian ini adalah mahasiswa baru di Program Studi S1 Psikologi Fakultas Psikologi Universitas Kristen Satya Wacana angkatan 2019 yang berjumlah 310 mahasiswa. Sampel diambil sebanyak 227 mahasiswa yang diperoleh dengan cara peneliti menawarkan keikutsertaan kepada mahasiswa angkatan 2019 di kelas perkuliahan yang wajib diikuti mahasiswa baru, yaitu kelas Pengembangan Diri. Mahasiswa yang tidak bersedia menjadi partisipan atau tidak hadir saat pertemuan tersebut tidak dilibatkan dalam penelitian.

Alat ukur yang digunakan dalam penelitian ini berupa skala psikologi yang diisi sendiri oleh partisipan penelitian (self-report questionnaire). Kuesioner yang digunakan adalah Student Adjustment to College Questionnaire yang dikembangkan oleh Baker dan Siryk (1984) dan diterjemahkan ke dalam Bahasa Indonesia oleh peneliti. Jika ada pernyataan yang kurang sesuai dengan kondisi mahasiswa Indonesia, maka pernyataan tersebut diubah konteksnya dengan melihat kembali esensi dari item tersebut dalam teori SACQ. SACQ yang dikembangkan oleh Baker dan Siryk terdiri dari 4 subskala yaitu penyesuaian akademik, penyesuaian sosial, penyesuaian personal-emosional, dan kelekatan institusional. Kuesioner SACQ ini terdiri dari item positif dan negatif yang tersebar secara acak dengan skala pengukuran yang digunakan ialah dengan skala likert yang memiliki rentang skor 1-4 dan terdiri dari 67 pernyataan. Hasil penerjemahan ini kemudian diujicobakan pada beberapa mahasiswa untuk mengetahui apakah kalimat pernyataan dalam kuesioner tersebut dapat dipahami. Dari hasil diskusi tersebut, terdapat beberapa pernyataan yang direvisi kalimatnya supaya lebih mudah dipahami mahasiswa.

Adaptasi kuesioner yang telah direvisi kemudian diujikan kepada 609 mahasiswa di Fakultas Psikologi UKSW. Hasil pengujian reliabilitas alat ukur yang telah diadaptasi peneliti ke dalam bahasa Indonesia menunjukkan bahwa subskala penyesuaian akademik (academic adjustment) memiliki nilai Cronbach alpha $a=0,806$, subskala penyesuaian sosial (social adjustment) memiliki nilai Cronbach alpha $a=0,822$; subskala penyesuaian personal-emosional (personal-emotional adjustment) memiliki nilai Cronbach alpha $a=0,816$; dan subskala kelekatan institusional (institutional attachment) memiliki nilai Cronbach alpha $a=0,791$. Dari 67 item dalam Student Adjustment to College Questionnaire, terdapat 8 item (item no 36, 22, 33, 26, 24, 49, 53, 67) yang dieliminasi karena memiliki skor 
corrected item total correlation di bawah 0,2 sehingga dianggap tidak memuaskan.

Data dari masing-masing partisipan penelitian ini akan diolah untuk mengetahui skor penyesuaian di perguruan tinggi dari setiap subskala. Hasil pengolahan tersebut kemudian akan dikategorikan menjadi 3 kelompok kategori, yaitu tinggi, sedang dan rendah (lihat tabel 1).

Tabel 1. Kategorisasi Skor Penyesuaian Mahasiswa di Perguruan Tinggi pada setiap Subskala

\begin{tabular}{lccclc}
\hline Subskala & Mean & SD & $\begin{array}{l}\text { Kategori } \\
\text { Rendah }\end{array}$ & $\begin{array}{l}\text { Kategori } \\
\text { Sedang }\end{array}$ & $\begin{array}{l}\text { Kategori } \\
\text { Tinggi }\end{array}$ \\
\hline $\begin{array}{l}\text { Academic } \\
\text { Adjustment }\end{array}$ & 65,76 & 6,59 & $<59.16$ & $59.16-72.36$ & $>72.36$ \\
\hline $\begin{array}{l}\text { Social } \\
\text { Adjustment }\end{array}$ & 49,11 & 6,10 & $<43$ & $43-55.21$ & $>55.21$ \\
\hline $\begin{array}{l}\text { Personal- } \\
\text { Emotional } \\
\text { Adjustment }\end{array}$ & 33,70 & 5,95 & $<27,74$ & $27,74-39,66$ & $>39,66$ \\
\hline $\begin{array}{l}\text { Institutional } \\
\text { Attachment }\end{array}$ & 24,30 & 3,15 & $<21,15$ & $21,15-27,46$ & $>27,46$ \\
\hline
\end{tabular}

Analisis statistik dilakukan dengan pengujian parametrik dan non-parametrik untuk mengetahui signifikansi perbedaan penyesuaian akademik, sosial, di perguruan tinggi ditinjau dari jenis kelamin, asal daerah, dan tempat tinggal saat ini.

Sebelum melakukan uji beda, peneliti melakukan uji asumsi terlebih dahulu untuk menentukan metode uji beda parametrik atau non-parametrik. Uji asumsi yang akan dilakukan meliputi uji normalitas dan homogenitas varian. Uji normalitas data dalam penelitian ini dilakukan dengan uji Kolmogorov-Smirnov $(K-S)$ dengan kriteria skor sig. > 0,05 (di atas 0,05) maka distribusi dianggap normal. Sedangkan untuk uji homogenitas varian akan dilakukan dengan uji Levene's Test for Homogenity of Variance, dengan kriteria skor sig. > 0,05 (diatas 0,05) maka varians antar kelompok dianggap homogen. Dalam seluruh uji beda (baik menggunakan uji-T maupun dengan ANOVA) yang dilakukan dalam penelitian ini, peneliti menggunakan standar $\alpha=5 \%$ yang artinya hipotesis diterima (ada perbedaan signifikan) apabila nilai Sig. dalam pengujian < 0,05 (lebih kecil dari 0,05).

Berdasarkan hasil uji normalitas data dan homogenitas varians disimpulkan bahwa uji beda parametrik (uji T dan ANOVA) dapat dilakukan pada seluruh uji beda terkait dengan dimensi penyesuaian akademik, penyesuaian sosial dan penyesuaian personalemosional. Uji beda non-parametrik (Mann-Whitney dan Kruskall-Wallis) dilakukan untuk seluruh uji beda pada dimensi kelekatan institusional karena terdapat beberapa kelompok uji yang datanya tidak berdistribusi normal.

\section{HASIL DAN PEMBAHASAN}

Sebanyak 227 mahasiswa telah menjadi partisipan dalam penelitian ini dengan karakteristik demografi seperti yang dipaparkan dalam tabel 2 .

Peneliti kemudian melakukan kategorisasi data dari skor partisipan dari setiap subskala. Penjabaran dari kategorisasi data partisipan dapat dilihat pada tabel 3 . Dari tabel 3, dapat dilihat bahwa sebagian besar mahasiswa menunjukkan skor penyesuaian akademik sedang $(70,04 \%)$ dan tinggi $(14,98 \%)$, sementara hanya $14,98 \%$ di antara mahasiswa yang diteliti menunjukkan skor penyesuaian akademik yang rendah. Artinya, mahasiswa angkatan baru Fakultas Psikologi UKSW cenderung menilai bahwa respons mental maupun tingkah laku mereka sudah cukup efektif untuk menghadapi tuntutan yang ada pada area akademik di lingkungan Fakultas Psikologi UKSW. Meski demikian, terdapat $14,98 \%$ mahasiswa tahun pertama yang merasa bahwa respons mental dan tingkah laku mereka belum dapat menjawab tuntutan akademik di lingkungan Fakultas Psikologi UKSW.

Penyesuaian akademik terbentuk dari beberapa aspek, yaitu motivasi untuk berkuliah dan mengerjakan tugastugas perkuliahan, yang kemudian diterjemahkan ke dalam usaha akademik yang nyata dalam menjawab tuntutan akademik, dan didukung dengan keyakinan akan kemampuan diri untuk mencapai keberhasilan dari usaha yang telah dilakukan serta rasa puas terhadap situasi akademik di lingkungan universitas (Baker \& Siryk, 1984). Implikasi dari aspek-aspek ini tergambarkan dari beberapa penelitian yang dilaporkan oleh Baker (2002) yang menunjukkan bahwa mahasiswa dengan penyesuaian akademik yang lebih baik diprediksi memiliki prestasi belajar yang lebih baik, melaporkan tingkat membolos yang lebih rendah, dan cenderung memiliki penyesuaian akademik yang lebih baik di tahun kedua (Hurtado, Carter, \& Spuler, 1996).

Tabel 2. Data Demografi Partisipan Penelitian

\begin{tabular}{|c|c|c|c|}
\hline \multicolumn{2}{|c|}{ Data Demografi } & \multirow{2}{*}{$\begin{array}{l}\text { Frekuensi } \\
53 \\
\end{array}$} & \multirow{2}{*}{$\begin{array}{l}\text { Persentase } \\
23,35 \%\end{array}$} \\
\hline Jenis & Laki-laki & & \\
\hline kelamin & Perempuan & 174 & $76,65 \%$ \\
\hline \multirow{3}{*}{$\begin{array}{l}\text { Asal } \\
\text { Daerah }\end{array}$} & $\begin{array}{l}\text { Penduduk lokal } \\
\text { (Salatiga) }\end{array}$ & 43 & $18,94 \%$ \\
\hline & $\begin{array}{l}\text { Pendatang (Pulau } \\
\text { Jawa) }\end{array}$ & 76 & $33,48 \%$ \\
\hline & Pendatang (Luar Jawa) & 108 & $47,58 \%$ \\
\hline \multirow{5}{*}{$\begin{array}{l}\text { Tempat } \\
\text { Tinggal } \\
\text { saat ini }\end{array}$} & Bersama keluarga & 57 & $25,11 \%$ \\
\hline & Tinggal sendiri di: & & \\
\hline & a. Kost & 153 & $67,40 \%$ \\
\hline & $\begin{array}{l}\text { bontrak dengan } \\
\text { mahasiswa lain }\end{array}$ & 14 & $6,17 \%$ \\
\hline & c. Asrama & 3 & $1,32 \%$ \\
\hline \multirow{4}{*}{$\begin{array}{l}\text { Status } \\
\text { Sosial } \\
\text { Ekonomi } \\
\text { Keluarga }\end{array}$} & Berkelebihan & 1 & $0,44 \%$ \\
\hline & Berkecukupan & 203 & $89,43 \%$ \\
\hline & Pas-pasan & 22 & $9,69 \%$ \\
\hline & Berkekurangan & 1 & $0,44 \%$ \\
\hline
\end{tabular}

Tabel 3. Kategori Skor Penyesuaian Mahasiswa di Perguruan Tinggi

\begin{tabular}{|c|c|c|c|c|c|}
\hline \multicolumn{2}{|c|}{ Tinggi } & \multicolumn{2}{|c|}{ Sedang } & \multicolumn{2}{|c|}{ Rendah } \\
\hline $\mathbf{N}$ & $\%$ & $\mathbf{N}$ & $\%$ & $\mathbf{N}$ & 0 \\
\hline
\end{tabular}




\begin{tabular}{lcccccc}
\hline $\begin{array}{l}\text { Academic } \\
\text { Adjustment }\end{array}$ & 34 & 14,98 & 159 & 70,04 & 34 & 14,98 \\
\hline $\begin{array}{l}\text { Social } \\
\text { Adjustment }\end{array}$ & 32 & 14,10 & 173 & 76,21 & 22 & 9,69 \\
\hline $\begin{array}{l}\text { Personal- } \\
\text { Emotional } \\
\text { Adjustment }\end{array}$ & 34 & 14,98 & 158 & 69,60 & 35 & 15,4 \\
\hline $\begin{array}{l}\text { Institutional } \\
\text { Attachment }\end{array}$ & 39 & 17,18 & 144 & 63,44 & 44 & 19,38 \\
\hline
\end{tabular}

Hal ini memiliki arti bahwa mayoritas mahasiswa tahun pertama Fakultas Psikologi menilai diri mereka memiliki dorongan yang cukup untuk berkuliah dan sudah mampu untuk mengalirkan motivasi tersebut menjadi usaha yang nyata, merasa yakin bahwa dirinya mampu berhasil dalam perkuliahan melalui usaha yang nyata, merasa yakin bahwa dirinya mampu berhasil dalam perkuliahan melalui usaha yang ia lakukan, dan merasa puas dengan situasi akademik di lingkungan universitas. Mengingat bahwa subskala ini dapat berimplikasi pada prestasi belajar, tingkat membolos dan penyesuaian akademik mahasiswa di tahun berikutnya, sejumlah 14,98\% mahasiswa yang melaporkan dirinya berada pada kategori penyesuaian akademik yang tergolong kurang perlu menjadi diperhatikan.

Selanjutnya, pada subskala penyesuaian sosial, sebagian besar mahasiswa tahun pertama Fakultas psikologi UKSW memeroleh skor yang tergolong sedang $(76,21 \%)$ dan tinggi $(14,10 \%)$. Artinya, mayoritas mahasiswa tahun pertama menilai diri mereka telah dapat menunjukkan respons mental dan perilaku untuk menunjukkan respons mental dan perilaku untuk menjawab tuntutan interpersonal dan sosial di lingkungan Fakultas Psikologi UKSW. Di sisi lain, masih terdapat 9,69\% mahasiswa yang memeroleh skor rendah pada subskala ini, yang artinya mereka menilai bahwa respons mental dan perilaku mereka masih kurang untuk menjawab tuntutan sosial di lingkungan Fakultas Psikologi UKSW.

Penyesuaian sosial dapat dilihat dari derajat keterlibatan dan kesuksesan mahasiswa dalam aktivitas dalam aktivitas sosial dan keberfungsian sosialnya secara umum, keterlibatannya dengan orang lain yang ada di kampus, keberhasilannya dalam menyesuaikan diri atas perpisahannya dengan keluarga dan orang lain yang signifikan di daerah asalnya, serta perasaan puas dengan lingkungan sosial yang dihadapi saat ini (Baker \& Siryk, 1989). Beberapa penelitian terdahulu menunjukkan bahwa bahwa mahasiswa dengan penyesuaian sosial yang lebih tinggi cenderung lebih terlibat dalam kehidupan di kampus, contohnya yaitu lebih berpartisipasi dalam kegiatan ekstrakurikuler yang ditawarkan oleh kampus (Baker, 2002). Selain itu, Baker (2002) juga memaparkan beberapa hasil penelitian yang menunjukkan bahwa mahasiswa dengan penyesuaian sosial tinggi melaporkan bahwa mereka merasa nyaman untuk mengenali lingkungan kampusnya, pulang ke rumah lebih jarang sementara perkuliahan masih berjalan, serta memiliki lebih banyak teman dekat. Sementara itu, mahasiswa tahun pertama dengan penyesuaian sosial yang lebih rendah biasanya mengalami kesulitan menyesuaikan diri karena cenderung kurang terlibat dalam aktivitas sosial yang ditawarkan oleh universitas dan fakultas, di mana hal ini juga dapat dikarenakan mahasiswa belum mampu mengatasi perasaan terpisah dari lingkungan di daerah asalnya. Kondisi ini dapat membuat mahasiswa menjadi merasa kesepian, kurang dapat berteman dengan orang lain dan terisolasi dari lingkungan sosialnya saat ini.

Melihat bahwa mayoritas mahasiswa tahun pertama Fakultas Psikologi memiliki penyesuaian sosial sedang dan tinggi, dapat ditarik kesimpulan bahwa kebanyakan dari mereka menilai bahwa dirinya sudah dapat terlibat dalam berbagai aktivitas sosial dan lingkungan sosial (seperti teman sebaya, senior, maupun staf kependidikan dan staf pendidik). di kampus. Mereka juga merasa sudah mampu meregulasi perpisahan dengan orang-orang yang signifikan bagi mereka (significant others) dari daerah asalnya serta merasa puas dengan relasi dan lingkungan sosial saat ini. Meskipun demikian, masih terdapat sebagian kecil mahasiswa yang melaporkan skor penyesuaian sosial yang rendah. Hal ini mengindikasikan bahwa dibandingkan dengan teman-teman seangkatannya, mereka merasa kesulitan untuk terlibat dengan lingkungan sosialnya, lebih sulit menjalin relasi yang hangat dan akrab dengan orang lain di lingkungan kampus, masih belum mampu meregulasi perpisahannya dengan orang-orang yang signifikan bagi mereka dari daerah asal, serta relatif kurang puas dengan situasi lingkungan sosial di perguruan tinggi.

Pada subskala ketiga (penyesuaian personalemosional) terdapat dua aspek, yaitu penilaian individu terhadap kesejahteraan psikologis yang dirasakan dan kesehatan fisik individu ketika menghadapi proses penyesuaian di lingkungan yang baru. Tabel 3 menunjukkan bahwa sebanyak 69,60\% mahasiswa tahun pertama memiliki skor penyesuaian personal-emosional yang sedang dan 14,98\% memiliki skor tinggi. Artinya, mayoritas mahasiswa yang menjadi responden penelitian menilai bahwa mereka memiliki kesejahteraan psikologis dan kondisi fisik yang cukup dan baik serta tidak merasa terganggu selama proses penyesuaian diri di perguruan tinggi. Di sisi lain, masih terdapat $15,42 \%$ mahasiswa yang melaporkan bahwa ada gangguan terhadap kesejahteraan psikologis dan fisik mereka ketika menjalani proses penyesuaian semasa berkuliah.

Kondisi kesejahteraan psikologis mahasiswa tahun pertama Fakultas Psikologi UKSW yang terganggu dalam proses penyesuaian di perguruan tinggi biasanya muncul dalam bentuk kecemasan, ketegangan, atau distres psikologis (psychological distress) selama masa perkuliahan sedangkan, gangguan kesehatan fisik dalam masa penyesuaian ini biasanya muncul dalam bentuk seperti gangguan pencernaan, gangguan pernafasan, sakit kepala, sakit punggung, dan kelelahan. Schneider (1964, dalam Budiyanto, 2015) menjelaskan bahwa individu yang mengalami kesulitan dalam proses penyesuaian diri berarti individu tersebut belum dapat meredakan 
ketegangan yang berasal dari kegagalannya untuk memberikan respons yang sesuai untuk memenuhi tuntutan lingkungan. Selain itu, Hussain et al. (2008, dalam Wedyaswari et al., 2019) menyatakan bahwa stres tidak hanya memengaruhi performa akademik tetapi juga dapat memengaruhi kondisi mahasiswa dalam aspek yang lebih luas seperti penyesuaian diri. Kondisi ini membuat mahasiswa dengan penyesuaian personal-emosional yang rendah akan cenderung lebih sering membutuhkan pelayanan kesehatan karena sakit atau bantuan untuk pelayanan kesehatan mental seperti konseling atau psikoterapi (Baker, 2002).

Pada subskala kelekatan institusional, tabel 3 menunjukkan bahwa sebanyak 63,44\% mahasiswa baru menilai bahwa mereka cukup puas dengan keputusan untuk melanjutkan studi di UKSW dan merasakan keterikatan yang cukup kuat dengan Fakultas Psikologi secara khusus. Sebanyak 17,18\% mahasiswa baru menilai bahwa mereka puas dengan keputusan untuk melanjutkan studi di UKSW dan merasakan keterikatan yang kuat dengan Fakultas Psikologi secara khusus. Sementara itu, sebanyak 19,38\% dari mahasiswa baru merasa kurang puas dengan keputusan mereka untuk berkuliah di UKSW serta tidak memiliki keterikatan yang cukup dengan UKSW secara khusus dan/atau di Fakultas Psikologi UKSW.

Kelekatan institusional memiliki dua aspek yaitu penilaian individu terhadap kepuasan berada di universitas secara umum dan kepuasan untuk berada di institusi dan jurusan yang saat ini sedang dijalani. Kebanyakan mahasiswa tahun pertama Fakultas Psikologi UKSW menunjukkan bahwa mereka merasa puas dengan keputusan untuk berkuliah dan memiliki keinginan yang relatif kuat untuk menyelesaikan studi hingga mencapai gelar sarjana. Selain itu, mahasiswa pada kelompok ini juga merasa cukup puas dengan keputusannya untuk berkuliah di UKSW dan memilih jurusan psikologi. Berdasarkan hal ini, mahasiswa dengan skor kelekatan institusional yang sedang maupun tinggi cenderung memiliki kemungkinan yang lebih kecil untuk mengundurkan diri dari kampus atau pindah ke universitas lainnya. Di sisi lain, mahasiswa tahun pertama Fakultas Psikologi UKSW yang melaporkan kelekatan institusional yang berada pada kategori rendah memiliki tingkat kepuasan yang lebih rendah terhadap keputusannya untuk berkuliah maupun berkuliah di UKSW serta menunjukkan keinginan yang lebih rendah untuk menyelesaikan studi hingga mencapai gelar sarjana. Feldt et al. (2011) menjelaskan mahasiswa dengan skor rendah pada subskala ini akan cenderung untuk memandang bahwa institusi yang ssedang dijalani saat ini dirasa kurang cocok dengan dirinya.

Jika kita membandingkan hasil pada keempat subskala, kelekatan institusional menunjukkan jumlah mahasiswa dengan skor tergolong rendah yang paling banyak, yaitu sebesar 19,38\%. Artinya mahasiswa yang mengalami kesulitan dalam penyesuaian terkait dengan kepuasan terhadap keputusan untuk berkuliah dan melanjutkan studi di UKSW berjumlah lebih banyak dibandingkan mahasiswa yang mengalami kesulitan penyesuaian pada dimensi lainnya.

Terdapat beberapa hal yang dapat membuat mahasiswa cenderung kurang puas terhadap keputusannya untuk melanjutkan studi di universitas dan jurusan yang sedang dijalani saat ini serta kurang memiliki keterikatan dengan institusi. Persepsi mahasiswa tahun pertama tentang kurangnya kecocokan dengan institusi mungkin tidak akurat karena kurangnya pengetahuan tentang sumber daya dan dukungan yang dapat diberikan oleh universitas (Feldt et al., 2011). Jika tidak diatasi dengan optimal, hal ini dapat meningkatkan kemungkinan mahasiswa mengundurkan diri atau meninggalkan universitas/jurusan ketika mengalami kesulitan atau hambatan selama berkuliah. Kelekatan institusional yang rendah juga lebih sering ditemui pada kelompok mahasiswa yang masuk ke perguruan tinggi atau jurusan yang bukan merupakan pilihan utamanya (Baker, 2002). Dengan kata lain, mahasiswa yang melanjutkan kuliah atas pilihannya sendiri dan menentukan universitas dan fakultasnya sendiri cenderung melaporkan kelekatan institusional yang lebih tinggi. Pilihan universitas dan jurusan yang berdasarkan pada keputusan mahasiswa ini membuat mahasiswa memiliki motivasi yang kuat untuk bertahan di universitas dan jurusannya saat ini serta merasa puas dengan lingkungan yang ia temui.

Selanjutnya, peneliti melakukan uji beda terhadap keempat subskala penyesuaian mahasiswa di perguruan tinggi ditinjau dari jenis kelamin, asal mahasiswa, dan jenis tempat tinggal mahasiswa selama berkuliah untuk mengetahui signifikansi perbedaan tingkat penyesuaian mahasiswa di perguruan tinggi berdasarkan data demografi tersebut.

Tabel 4. Hasil Uji Beda Tingkat Penyesuaian di Perguruan Tinggi Mahasiswa

\begin{tabular}{|c|c|c|c|c|c|}
\hline $\begin{array}{c}\text { Dimensi } \\
\text { SACQ }\end{array}$ & Variabel & $\begin{array}{c}\begin{array}{c}\text { Kelompok uji } \\
\text { beda }\end{array} \\
\end{array}$ & Mean & SD & $p$ \\
\hline \multirow{7}{*}{$\begin{array}{l}\text { Academic } \\
\text { Adjustment }\end{array}$} & \multirow{2}{*}{ Jenis kelamin } & Pria & 65,6 & 6,314 & \multirow{2}{*}{0,063} \\
\hline & & Wanita & 57,4 & 6,032 & \\
\hline & \multirow{3}{*}{ Asal Daerah } & Penduduk lokal & 66,3 & 6,801 & \multirow{3}{*}{0,04} \\
\hline & & Pulau Jawa & 65,8 & 5,419 & \\
\hline & & $\begin{array}{l}\text { Luar Pulau } \\
\text { Jawa }\end{array}$ & 68,0 & 6,214 & \\
\hline & \multirow{2}{*}{$\begin{array}{l}\text { Jenis tempat } \\
\text { tinggal }\end{array}$} & Tinggal Sendiri & 67,3 & 6,116 & \multirow{2}{*}{0,193} \\
\hline & & $\begin{array}{l}\text { Bersama } \\
\text { keluarga }\end{array}$ & 66,0 & 6,141 & \\
\hline \multirow{7}{*}{$\begin{array}{l}\text { Social } \\
\text { Adjustment }\end{array}$} & \multirow{2}{*}{ Jenis kelamin } & Pria & 49,9 & 6,301 & \multirow{2}{*}{0,257} \\
\hline & & Wanita & 48,9 & 6,038 & \\
\hline & \multirow{3}{*}{ Asal Daerah } & Penduduk lokal & 48,4 & 5,781 & \multirow{3}{*}{0,695} \\
\hline & & Pulau Jawa & 49,1 & 5,142 & \\
\hline & & $\begin{array}{l}\text { Luar Pulau } \\
\text { Jawa }\end{array}$ & 49,4 & 6,845 & \\
\hline & \multirow{2}{*}{$\begin{array}{l}\text { Jenis tempat } \\
\text { tinggal }\end{array}$} & Tinggal Sendiri & 49,4 & 6,248 & \multirow{2}{*}{0,217} \\
\hline & & $\begin{array}{l}\text { Bersama } \\
\text { keluarga }\end{array}$ & 48,2 & 5,617 & \\
\hline \multirow{2}{*}{$\begin{array}{l}\text { Personal- } \\
\text { emotional } \\
\text { adjustment }\end{array}$} & \multirow{2}{*}{ Jenis kelamin } & Pria & 36,4 & 5,296 & \multirow{2}{*}{0,001} \\
\hline & & Wanita & 32,9 & 5,917 & \\
\hline
\end{tabular}




\begin{tabular}{|c|c|c|c|c|c|}
\hline & \multirow{3}{*}{ Asal Daerah } & Penduduk lokal & 34,9 & 6,005 & \multirow{3}{*}{0,367} \\
\hline & & Pulau Jawa & 33,5 & 5,760 & \\
\hline & & $\begin{array}{l}\text { Luar Pulau } \\
\text { Jawa }\end{array}$ & 33,4 & 6,073 & \\
\hline & \multirow{2}{*}{$\begin{array}{l}\text { Jenis tempat } \\
\text { tinggal }\end{array}$} & Tinggal Sendiri & 33,3 & 6,011 & \multirow{2}{*}{0,073} \\
\hline & & $\begin{array}{l}\text { Bersama } \\
\text { keluarga }\end{array}$ & 34,9 & 5,663 & \\
\hline \multirow{7}{*}{$\begin{array}{l}\text { Institutio- } \\
\text { nal } \\
\text { Attachment }\end{array}$} & \multirow{2}{*}{ Jenis kelamin } & Pria & 20,8 & 2,808 & \multirow{2}{*}{0,601} \\
\hline & & Wanita & 21,0 & 2,757 & \\
\hline & \multirow{3}{*}{ Asal Daerah } & Penduduk lokal & 20,1 & 2,555 & \multirow{3}{*}{0,007} \\
\hline & & Pulau Jawa & 20,7 & 2,821 & \\
\hline & & $\begin{array}{l}\text { Luar Pulau } \\
\text { Jawa }\end{array}$ & 21,4 & 2,733 & \\
\hline & \multirow{2}{*}{$\begin{array}{l}\text { Jenis tempat } \\
\text { tinggal }\end{array}$} & Tinggal Sendiri & 21,2 & 2,834 & \multirow{2}{*}{0,002} \\
\hline & & $\begin{array}{l}\text { Bersama } \\
\text { keluarga }\end{array}$ & 20,2 & 2,426 & \\
\hline
\end{tabular}

Hasil uji T (lihat tabel 4) menunjukkan tidak adanya perbedaan penyesuaian akademik yang signifikan di antara responden laki-laki dan perempuan dengan nilai signifikansi adalah 0,063 (p > 0,05) dan di antara mahasiswa yang tinggal sendiri dibanding yang tinggal bersama keluarga dengan nilai signifikansi 0,971 (p > 0,05). Meski demikian, perbedaan signifikan ditemukan pada skor penyesuaian akademik ditinjau dari asal mahasiswa (penduduk lokal, pendatang dari Pulau Jawa, dan pendatang dari luar Pulau Jawa) dengan nilai signifikansi 0,042 (p < 0,05). Post-hoc test (menggunakan Tukey's Post-hoc Test) yang dilakukan setelahnya menunjukkan bahwa perbedaan signifikan ditemukan di antara mahasiswa yang berasal dari Pulau Jawa dan mahasiswa yang berasal dari luar Pulau Jawa (mean difference $=2,17$ ).

Dari hasil pengujian ini, diperoleh hasil bahwa pada subskala penyesuaian akademik hanya ditemukan perbedaan signifikan pada kelompok mahasiswa pendatang dari Jawa dengan mahasiswa dari Luar Jawa. Temuan ini merupakan hasil yang menarik, di mana perbedaan signifikan yang ditemukan di antara mahasiswa yang berasal dari Pulau Jawa dan mahasiswa yang berasal dari luar Pulau Jawa, dengan skor rata-rata mahasiswa pendatang dari Luar Jawa lebih tinggi dibandingkan dengan skor rata-rata mahasiswa pendatang dari Pulau Jawa.

Penelitian yang dilakukan Mitasari dan Istikomayanti (2017) menyatakan bahwa mahasiswa pendatang yang berasal dari luar Jawa di Malang cenderung mengalami culture shock di tahun pertama kuliah. Ketika menghadapi situasi ini, mahasiswa pendatang berupaya untuk melakukan penyesuaian diri dengan aktif menjalin pertemanan dengan mahasiswa lain. Jika melihat pada lingkungan Fakultas Psikologi UKSW, jumlah mahasiswa yang berasal dari luar Pulau Jawa lebih banyak dibandingkan mahasiswa lokal dan mahasiswa pendatang dari Jawa. Banyaknya teman yang berasal dari daerah yang sama dan terlibat dalam organisasi mahasiswa mungkin membantu mempercepat penyesuaian akademik mahasiswa yang berasal dari luar Jawa baik dalam proses pembelajaran di kelas maupun dalam mengerjakan tugas kelompok dibandingkan dengan mahasiswa dari daerah lain yang jumlahnya relatif lebih sedikit.

Hasil pengujian tingkat penyesuaian akademik ditinjau dari jenis kelamin dalam penelitian ini berbeda dengan penelitian yang dilakukan oleh Wider et al. (2016) yang menyatakan bahwa terdapat perbedaan signifikan antara penyesuaian akademik antara mahasiswa perempuan dan laki-laki di mana mahasiswa perempuan memiliki penyesuaian akademik yang lebih tinggi dari mahasiswa laki-laki. Di sisi lain, hasil penelitian ini serupa dengan temuan yang dikemukakan oleh Aderi, et al. (2013) yang menyatakan bahwa tidak terdapat perbedaan penyesuaian akademik yang signifikan antara mahasiswa laki-laki dan perempuan. Penelitian yang melakukan uji beda terhadap skor penyesuaian akademik pada laki-laki dan perempuan memang masih memunculkan hasil-hasil yang berbeda-beda. Penelitian yang dilakukan oleh Fernandez et al. (2017) menunjukkan hasil bahwa hubungan antara jenis kelamin dengan penyesuaian akademik hanya muncul ketika dimediasi oleh variabel prestasi pra-kuliah (preuniversity achievement). Hal ini menunjukkan bahwa jenis kelamin mungkin memiliki kaitan dengan tingkat penyesuaian akademik pada mahasiswa dengan mediasi dari variabel lainnya. Namun pada penelitian ini, peneliti belum melibatkan variabel lain sebagai variabel mediasi antara jenis kelamin dengan penyesuaian akademik.

Berdasarkan Uji $\mathrm{T}$ yang telah dilakukan, tidak ditemukan adanya perbedaan penyesuaian sosial di antara responden berjenis kelamin laki-laki dan perempuan, dengan nilai signifikansi $0,257(p>0,05)$ serta antara responden yang tinggal sendiri dibanding yang tinggal bersama keluarga dengan nilai signifikansi 0,296 (p > 0,05). Uji ANOVA yang dilakukan untuk mencari perbedaan penyesuaian sosial berdasarkan asal mahasiswa menunjukkan nilai signifikansi 0,695 (p > 0,05 ), yang artinya tidak ada perbedaan penyesuaian sosial yang signifikan di antara mahasiswa yang berasal dari Salatiga, Pulau Jawa, dan luar Pulau Jawa.

Hasil penelitian ini serupa dengan hasil penelitian sebelumnya yang menyatakan bahwa tidak terdapat perbedaan signifikan antara tingkat penyesuaian sosial mahasiswa laki-laki dan perempuan (Fernandez et al., 2017; Zubir, 2012). Selain itu, pada faktor tempat tinggal mahasiswa, penelitian ini mendapatkan hasil yang serupa dengan hasil penelitian Beyers dan Goossens (2002, dalam Baker, 2002), pada mahasiswa tahun pertama di Universitas Belgia yang tinggal sendiri di sekitar kampus dan pulang ke rumah orangtua setiap akhir pekan atau libur, dengan mahasiswa yang tinggal bersama keluarganya yaitu bahwa tidak ada perbedaan penyesuaian sosial kedua kelompok tersebut. Penelitian lain yang dilakukan oleh Mooney et al. (1991) juga menunjukkan hasil serupa di mana tidak terdapat kaitan antara jarak geografis dari daerah asal dengan penyesuaian mahasiswa, namun terdapat perbedaan penyesuaian mahasiswa jika dikaji dari persepsi mahasiswa terhadap jarak antara daerah asalnya dengan 
tempat studi saat ini. Mahasiswa yang menilai bahwa jarak daerah asal mereka "cukup" memiliki tingkat penyesuaian yang lebih baik daripada mahasiswa yang menilai jarak daerah asal mereka "terlalu jauh".

Tidak adanya perbedaan pada tingkat penyesuaian sosial pada kelompok jenis kelamin, tempat tinggal dan daerah asal mahasiswa ini mungkin disebabkan karena penyesuaian sosial lebih melibatkan evaluasi mahasiswa terhadap derajat keterampilan sosial yang dimiliki untuk menjalin pertemanan, dan tingkat kepuasan terhadap pengalaman sosial (Feldt et al., 2011). Hal ini membuat tingkat penyesuaian sosial tampak lebih terkait dengan penilaian mahasiswa terhadap keterampilan sosial yang dimiliki, penilaian terhadap lingkungan saat ini, dan faktor kepribadian mahasiswa tersebut. Beberapa kajian terhadap penyesuaian sosial mahasiswa di perguruan tinggi juga menekankan pada faktor lain di luar diri mahasiswa seperti dukungan sosial (Paramo et al., 2014; Budiyanto, 2015; Martinez-Lopez et al., 2019). Mahasiswa yang tinggal sendiri di kos, asrama, atau kontrak bersama mahasiswa lain cenderung mendapatkan dukungan sosial dari teman di sekitar tempat tinggalnyasedangkan, mahasiswa yang tinggal bersama keluarga cenderung mendapatkan dukungan sosial dari keluarganya. Dengan demikian, mahasiswa dari berbagai latar belakang kelompok dapat memiliki tingkat penyesuaian sosial yang memadai ketika mereka mendapatkan dukungan sosial dari orang lain di sekitarnya, seperti teman kuliah, teman kos, maupun keluarga.

Pada dimensi penyesuaian personal-emosional hanya ditemukan perbedaan signifikan pada skor penyesuaian personal-emosional pada mahasiswa laki-laki dan perempuan, dengan skor penyesuaian personal emosional mahasiswa laki-laki memiliki rata-rata skor yang lebih tinggi daripada mahasiswa perempuan dengan nilai signifikansi 0,001 ( $\mathrm{p}<0,05)$. Uji beda di antara responden yang tinggal sendiri dibanding yang tinggal bersama keluarga menunjukkan tidak adanya perbedaan signifikan dengan nilai signifikansi 0,073 ( $\mathrm{p}>0,05)$, demikian juga uji ANOVA pada penyesuaian personalemosional berdasarkan asal mahasiswa tidak menunjukkan adanya perbedaan yang signifikan dengan nilai signifikansi 0,367 ( $\mathrm{p}>0,05)$.

Hasil penelitian ini serupa dengan hasil penelitian yang dilakukan oleh Addison (1996, dalam Baker 2002) yang menyatakan bahwa rata-rata skor mahasiswa lakilaki lebih tinggi daripada mahasiswa perempuan pada subskala penyesuaian personal-emosional. Penelitian yang dilakukan oleh Zubir (2012) di Universitas Indonesia, juga menghasilkan kesimpulan yang serupa, yaitu terdapat perbedaan signifikan pada subskala penyesuaian personal-emosional, di mana skor mahasiswa laki-laki lebih tinggi dibandingkan skor mahasiswa perempuan. Fernandez et al. (2017) menjelaskan bahwa mahasiswa perempuan menunjukkan kebutuhan yang lebih tinggi terhadap dukungan karena mereka cenderung lebih rentan terhadap masalah kecemasan, depresi dan masalah terkait identitas dalam proses mengatasi transisi ke universitas dibandingkan dengan mahasiswa laki-laki. Selain itu, beberapa hasil penelitian menunjukkan bahwa perempuan melaporkan tingkat stress yang lebih tinggi dibandingkan laki-laki (Arthur \& Hiebert, 1996) serta kecemasan yang lebih tinggi (Vivona, 2000 dalam Baker, 2002).

Selain faktor bahwa perempuan memiliki kecenderungan untuk mengalami stres yang lebih tinggi dibandingkan laki-laki, perbedaan antara penyesuaian personal-emosional pada mahasiswa laki-laki dan perempuan mungkin memiliki kaitan dengan kecenderungan perempuan untuk lebih sensitif terhadap gangguan fisik yang dialami (Leventhal et al., 1992). Penjelasan lain mengenai perbedaan laki-laki dan perempuan dalam merespons stres dan kondisi kesehatan fisik dalam proses penyesuaian di perguruan tinggi ini ialah terkait dengan norma sosial. Laki-laki diharapkan untuk menunjukkan diri yang tangguh, yang mungkin melibatkan pengabaian terhadap rasa sakit atau keluhan lainnya, sedangkan perempuan tidak memiliki tekanan sosial ini (Taylor, 2015). Sensitivitas terhadap gangguan fisik dan perbedaan tekanan sosial ini mungkin membuat mahasiswa perempuan cenderung melaporkan keluhan yang mereka alami baik emosional maupun fisik selama melalui masa transisi sehingga skor dalam subskala penyesuaian personal emosional mereka relatif lebih rendah dibandingkan dengan kelompok mahasiswa lakilaki.

Selanjutnya, uji Mann-Whitney menunjukkan tidak adanya perbedaan skor kelekatan institusional yang signifikan antara mahasiswa laki-laki dan perempuan dengan nilai signifikansi 0,601 ( $\mathrm{p}>0,05$ ). Hasil uji Kruskall-Wallis menunjukkan bahwa skor kelekatan institusional mahasiswa yang merupakan penduduk Salatiga, pendatang dari Pulau Jawa dan pendatang dari luar Pulau Jawa menunjukkan nilai signifikansi sebesar 0,007 ( $\mathrm{p}<0,05)$ dan hasil uji Mann-Whitney pada kelompok mahasiswa yang tinggal sendiri lebih tinggi daripada mahasiswa yang tinggal bersama keluarga dengan nilai signifikansi 0,002 ( $\mathrm{p}<0,05)$. Dengan demikian dapat disimpulkan bahwa terdapat perbedaan yang signifikan pada kelekatan institusional antara mahasiswa penduduk Salatiga, mahasiswa pendatang dari Pulau Jawa dan mahasiswa pendatang dari luar Pulau Jawa serta antara mahasiswa yang tinggal sendiri dengan mahasiswa yang tinggal bersama keluarga.

Hasil penelitian ini serupa dengan penelitianpenelitian sebelumnya yang menyatakan bahwa tidak terdapat perbedaan signifikan antara rata-rata skor kelekatan institusional pada mahasiswa laki-laki dan mahasiswa perempuan (Zubir, 2012; Fernandez et al., 2017; Jackson, 2008). Adapun kelekatan institusional ini merupakan evaluasi kepuasan mahasiswa terhadap keputusan untuk berkuliah dan memilih institusi saat ini sehingga wajar jika tidak terdapat perbedaan yang signifikan antara 2 kelompok jenis kelamin tersebut. Penelitian yang dilakukan pada mahasiswa tahun pertama di Belgia menunjukkan bahwa tidak terdapat perbedaan pada kelekatan institusional antara mahasiswa yang tinggal sendiri di sekitar kampus dan mahasiswa yang tinggal bersama keluarganya (Beyers \& Goossens, 2002). 
Hal ini berbeda dengan temuan di penelitian ini yang menyatakan bahwa terdapat perbedaan antara kelekatan institusional pada mahasiswa yang tinggal sendiri dengan tinggal bersama orang tua, serta mahasiswa lokal dengan mahasiswa pendatang dari Jawa dan mahasiswa pendatang dari Luar Jawa. Lebih lanjut, hasil uji beda ini menunjukkan bahwa mahasiswa pendatang dari luar Jawa memiliki skor rata-rata lebih tinggi dibandingkan mahasiswa lokal, dan mahasiswa yang tinggal sendiri memiliki skor rata-rata lebih tinggi daripada mahasiswa yang tinggal bersama keluarga.

Mohamed (2012) menjelaskan bahwa pengaturan tempat tinggal memang dapat menjadi salah satu faktor yang berkaitan dengan penyesuaian mahasiswa di perguruan tinggi yaitu, mahasiswa yang tinggal di rumah bersama keluarga justru kurang memiliki keuntungan yang dimiliki oleh mahasiswa yang tinggal di sekitar kampus. Demikian pula hasil temuan Jackson (2008) yang menunjukkan bahwa mahasiswa yang tinggal bersama keluarga, khususnya orangtua, memiliki tingkat kelekatan institusional yang lebih rendah dibandingkan kelompok mahasiswa yang tinggal di asrama kampus. Serupa dengan itu, Chickering dan Kytle (1999) menyatakan bahwa mahasiswa lokal dan tinggal bersama keluarga cenderung kurang terlibat dalam aktivitas akademik, sosial, dan ekstrakurikuler dibandingkan mahasiswa pendatang dan yang tinggal sendiri. Hal ini membuat mahasiswa lokal dan yang tinggal bersama keluarga kurang mengembangkan keterampilan personal dan kehilangan kesempatan pengalaman yang bermanfaat untuk pendidikan maupun tahapan berikutnya. Keterlibatan dalam kegiatan-kegiatan sosial dan ekstrakurikuler di kampus juga akan membuat mahasiswa mengembangkan kelekatan kepada institusi tempat ia belajar saat ini, karena mahasiswa akan menjadi semakin mengenal lingkungan di sekitar kampusnya dan mengetahui fasilitas dan layanan yang tersedia untuk membantu dalam proses studi.

Hasil dari kaitan antara pengaturan tempat tinggal dan daerah asal dengan penyesuaian mahasiswa juga tidak lepas dari berbagai aspek di lingkungan baru yang dihadapi oleh mahasiswa saat ini. Hal yang menarik dari lingkungan di UKSW pada umumnya dan Fakultas Psikologi pada khususnya ialah adanya organisasi kelompok etnis yang memiliki berbagai kegiatan bersama dan secara umum memiliki tujuan untuk menjalin kekeluargaan di antara sesama mahasiswa pendatang. Organisasi kelompok etnis ini menawarkan berbagai kegiatan seperti malam keakraban etnis, ibadah rutin disertai jamuan makan bersama, pendampingan dari senior yang berasal dari etnis yang sama, serta kegiatan kebudayaan seperti berlatih tari-tarian etnis untuk ditampilkan dalam acara budaya tahunan di UKSW. Suasana kekeluargaan dalam kegiatan-kegiatan komunitas ini membuat mahasiswa merasa dekat dengan suasana di daerah asalnya ketika memasuki lingkungan yang asing dalam masa transisi. Adanya komunitas dari daerah asal yang tersedia di universitas ini membuat mahasiswa pendatang dapat memiliki rasa kepuasan terhadap keputusannya untuk berada di institusi yang dipilihnya saat ini. Dukungan dari anggota komunitas juga dapat membuat mahasiswa merasa keinginan untuk bertahan dan menyelesaikan studi di universitas ini.

Di sisi lain, mahasiswa yang berasal dari kota Salatiga, atau penduduk lokal, justru tidak memiliki komunitas atau organisasi kelompok etnis di lingkungan kampus seperti mahasiswa pendatang. Hal ini membuat mahasiswa lokal tidak terlibat dalam kegiatan sosial sebanyak mahasiswa pendatang dan yang tinggal sendiri. Chapman dan Pascarella (1983, dalam Jackson, 2008) menyatakan bahwa mahasiswa yang merupakan penduduk lokal justru cenderung memiliki tingkat integrasi sosial dan rasa memiliki (sense of belonging) yang lebih rendah daripada mahasiswa pendatang dan mahasiswa yang tinggal sendiri. Sementara itu, perasaan terintegrasi dan memiliki institusi inilah yang membuat mahasiswa mengembangkan kelekatan institusional dengan universitas dan jurusan yang sedang ditempuhnya saat ini. Ketika mahasiswa lokal dan mahasiswa yang tinggal bersama dengan keluarganya kurang banyak terlibat dengan kegiatan-kegiatan di kampus, maka hal ini dapat membuat mahasiswa kurang memiliki kelekatan dengan institusi tempatnya melanjutkan studi.

Secara keseluruhan, masih terdapat sebagian mahasiswa yang melaporkan skor yang rendah pada setiap subskala (penyesuaian akademik $=14,98 \%$; penyesuaian sosial $=9,69 \%$; penyesuaian personalemosional $=15,42 \%$; dan kelekatan institusional $=$ 19,38\%). Implikasi dari temuan ini ialah universitas dan fakultas perlu untuk terus melanjutkan dan meningkatkan usaha-usaha untuk membantu mahasiswa dalam menyesuaikan diri, terutama dalam hal kelekatan institusional yang berhubungan erat dengan tingkat keinginan seseorang untuk menyelesaikan studi hingga sarjana (Gold et al., 1990).

Penelitian ini memiliki beberapa keterbatasan. Pertama, penelitian ini menggunakan metode kuantitatif, sehingga tidak dapat menyajikan data yang mendalam mengenai proses penyesuaian di perguruan tinggi mahasiswa tahun pertama Fakultas Psikologi UKSW. Selain itu, penelitian ini hanya dilakukan di satu fakultas saja, sehingga hasilnya tidak dapat digeneralisasikan pada kelompok mahasiswa baru di fakultas lain dan universitas lain. Ketiga, penelitian ini hanya membahas satu variabel, yaitu penyesuaian di perguruan tinggi dan beberapa faktor demografi saja, sehingga masih diperlukan penelitian lain untuk mencari tahu faktorfaktor yang berkontribusi terhadap tingkat penyesuaian mahasiswa di perguruan tinggi.

\section{SIMPULAN}

Sebagian besar mahasiswa tahun pertama di Fakultas Psikologi UKSW menunjukkan tingkat penyesuaian di perguruan tinggi pada dimensi akademik, 
sosial, personal-emosional dan institusional pada kategori sedang dan sebagian berada pada kategori tinggi. Artinya, mayoritas partisipan penelitian menilai bahwa respons mental maupun perilaku mereka telah cukup efektif untuk memenuhi tuntutan akademik, interpersonal, sosial yang diharapkan di lingkungan perguruan tinggi dan jurusan yang ditekuni sekarang, memiliki kesejahteraan psikologis dan kondisi fisik yang baik selama menjalani proses penyesuaian diri di perguruan tinggi, dan merasa puas saat menjalani kehidupan di perguruan tinggi yang dipilih serta memiliki keterikatan yang dibutuhkan dengan universitas maupun jurusan. Sebagian partisipan penelitian lainnya berada dalam kategori rendah, yang artinya masih terdapat kelompok mahasiswa yang menilai bahwa respons mental maupun perilaku mereka belum efektif untuk memenuhi tuntutan akademik, interpersonal, sosial yang diharapkan di lingkungan perguruan tinggi dan jurusan yang ditekuni sekarang, menilai bahwa kesejahteraan psikologis dan kondisi fisik terganggu selama menjalani proses penyesuaian diri di perguruan tinggi, dan kurang puas dalam menjalani kehidupan di perguruan tinggi yang dipilih serta memiliki keterikatan yang dibutuhkan dengan universitas maupun jurusan. Selain itu, hasil analisis uji beda menunjukkan bahwa terdapat perbedaan signifikan pada subskala penyesuaian akademik dan kelekatan institusional ditinjau dari daerah asal mahasiswa, di mana mahasiswa yang berasal dari luar Jawa memiliki tingkat penyesuaian akademik yang lebih tinggi dibandingkan mahasiswa lokal dan mahasiswa pendatang dari Jawa. Sementara pada subskala penyesuaian personal-emosional perbedaan ditemukan antara mahasiswa laki-laki dan perempuan, di mana mahasiswa laki-laki memiliki ratarata skor yang lebih tinggi. Perbedaan signifikan juga ditemukan pada subskala kelekatan institusional ditinjau dari faktor tempat tinggal mahasiswa, dimana mahasiswa dari luar Pulau Jawa memiliki rata-rata skor lebih tinggi daripada mahasiswa lokal, dan mahasiswa yang tinggal sendiri memiliki rata-rata skor lebih tinggi daripada mahasiswa yang tinggal bersama keluarga. Penelitian selanjutnya diharapkan dapat menelusuri faktor-faktor yang berkontribusi terhadap tingkat penyesuaian mahasiswa di perguruan tinggi seperti kompetensi sosial, kemandirian, dan kelekatan dengan orangtua. Selain itu, berdasarkan temuan penelitian ini, universitas dan fakultas dipandang perlu menyediakan program-program penyesuaian mahasiswa tahun pertama khususnya yang dapat meningkatkan kelekatan mahasiswa terhadap institusi tanpa mengesampingkan kegiatan yang dapat meningkatkan penyesuaian akademik, sosial dan personal-emosional.

\section{DAFTAR PUSTAKA}

Aderi, M., Jdaitawi, M., Ishak, N. A., \& Jdaitawi, F. (2013). The Influence of Demographic Variables on University Students' Adjustment in North Jordan. International Education Studies, 6, (2), 172-178.
Anderson, J. R. \& Guan, Y. (2017). Implicit Acculturation and the Academic Adjustment of China Sojourners in Australia. Australian Psychologist, November (2017), 1-10.

Arnett, J. J. (2000). Emerging Adulthood. A Theory of Development from the Late Teens Through the Twenties. American Psychologist, 55, (5), 469-480.

Arthur, N., \& Hiebert, B. (1996). Coping with the Transition to Post-Secondary Education. Canadian Journal of Counselling, 30, (2), 93-103.

Baker, R. W. \& Siryk, B. (1984). Measuring Adjustment to College. Journal of Counseling Psychology, 31, 179-189.

Baker, R. W. (2002). Research with the Student Adaptation to College Questionnaire (SACQ). https://www.mtholyoke.edu>shilkret >baker>BakerS ACQ.MS.doc

Beyers, W. \& Goossens, L. (2002). Concurrent and Predictive Validity of the Student Adaptation to College Questionnaire in a Sample of European Freshman Students. Educational and Psychological Measurement, 62, (3), 525-536. Doi: $10.1177 / 00164402062003009$

Bibi, S., Wang, Z., Ghaffari, A. S., \& Iqbal, Z. (2018). Social Achievement Goals and Academic Adjustment among College Students: Data from Pakistan. European Online Journal of Natural and Social Sciences, 7, (3), 588-593.

Budiyanto, E. A. (2015). Hubungan antara dukungan sosial dengan penyesuaian diri di lingkungan kampus pada mahasiswa Fakultas Psikologi Universitas Padjadjaran. Skripsi. Fakultas Psikologi Universitas Padjadjaran Bandung.

Chickering, A. W. and Kytle, J. (1999). The collegiate ideal in the twenty-first century. In J. D. Toma and A.J. Kezar (Eds.), Reconceptualizing the collegiate ideal (New directions higher education, No. 105) (pp. 109-120). San Francisco: Jossey-Bass.

Clinciu, A. I. \& Cazan, A. (2013). Academic Adjustment Questionnaire for the University Students. Procedia - Social and Behavioral Sciences, 127, 655-660.

Dawborn-Gundlach, M. \& Margetts, K. (2018). Social Adjustment and Transition to University for Mature-age, Undergraduate Students. Journal of Education and Social Policy, 5, (1), 88-96.

Feldt, R. C., Graham, M., \& Dew, D. (2011). Measuring Adjustment to College: Construct Validity of the Student Adaptation to College Questionnaire. Measurement and Evaluation in Counseling and Development, 44, (2), 92-104

Fernandez, M. F. P., Araujo, A. M., Vacas, C. T., Almeida, L. S., \& Gonzales, M. S. R. (2017). Predictors of Students' Adjustment During Transition to University in Spain. Psicothema, 29, (1), 67-72.

Fuad, F. T. \& Zarfiel, M. D. (2013). Hubungan antara penyesuaian diri di perguruan tinggi dan stres psikologis pada mahasiswa tahun pertama fakultas psikologi universitas indonesia. Skripsi. Fakultas Psikologi Universitas Indonesia. 
Gold, J., Burrell, S., Haynes, C., \& Nardecchia, D. (1990). Student Adaptation to College as a Predictor of Academic Success: An Exploratory Study of Black Undergraduate Education Students. (Research Report 143). (ERIC Document Reproduction Service No. ED 331 946.)

Handono, O. T. \& Bashori, K. (2013). Hubungan antara Penyesuaian Diri dan Dukungan Sosial Terhadap Stres Lingkungan pada Santri Baru. Empathy, Jurnal Fakultas Psikologi, 1, (2), 79-89.

Hurtado, S., Carter, D.F., Spuler, A. (1996). Latino Student Transtion to College: Assessing Difficulties and Factors in Successful College Adjustment. Research in Higher Education, 37, (2), 135-157.

Jackson, N. H. (2008). Factors related to nonacademic adjustment of freshmen students. Dissertation. University of Southern Mississipi.

Leventhal, H., Diefenbach, M., \& Leventhal, E. A. (1992). Illness Cognition: Using Common Sense to Understand Treatment Adherence and Affect Cognition Interactions. Cognitive therapy and research, 16, (2), 143-163.

Lidy, K. M. Kahn, J. H. (2006). Personality as a Predictor of First Semester Adjustment to College: The Meditational Role of Perceived Social Support. Journal of College Counselling, 9, 123-134.

Mariska, A. (2018). Pengaruh Penyesuaian Diri dan Kematangan Emosi terhadap Homesickness. Studi pada Mahasiswa Perantau Tahun Pertama, Angkatan 2017 FISIP, Universitas Mulawarman Samarinda. Psikoborneo, 6, (3), 670-680.

Martinez-Lopez, Z., Tinajero, C., Rodriguez, M.S., \& Paramo, M. F. (2019). Perceived Social Support and University Adjustment among Spanish College Students. European Journal of Psychology and Educational Research, 2, (1), 21-30.

Mitasari, Z. \& Istikomayanti, Y. (2018). Hubungan antara Culture Shock dengan Hasil Belajar Mahasiswa Tahun Pertama. Jurnal Psikologi Pendidikan dan Konseling, 4, (2), 105-113.

Mohamed, N. (2012). Adjustment to University: Predictors, Outcomes and Trajectories. Dissertation. University of Central Lancashire.

Mudhovozi, P. (2012). Social and Academic Adjustment of First-Year University Student. Journal of Social Science, 33 (2), 251-259.

Mutambara J. \& Bhebe V. (2012). An Analysis of the Factors Affecting Students' Adjustment at a University in Zimbabwe. Journal of International Education Studies, 5, (6), 244-250.

Mooney, S.P., Sherman, M.F., \& Lo Presto, C. T. (1991). Academic Locus of Control, Self-Esteem, and Perceived Distance from Home as Predictors of College Adjustment. Journal of counseling \& development, 69, 445-448.

Nurfitriana, P. (2016). Penyesuaian diri pada mahasiswa tahun pertama di Fakultas Psikologi Universitas
Muhammadiyah Surakarta. Skripsi. Fakultas Psikologi Universitas Muhammadiyah Surakarta.

Paramo, M. F., Martinez, Z., Tinajero, C., \& Rodriguez, M. S. (2014). The Impact of Perceived Social Support in First-Year Spanish College Students Adjustment. Journal of International Scientific Publications, 12, 289-300.

Parmaksiz, I. (2019). Assertiveness as the Predictor of Adjustment to University Life amongst University Students. International Journal of Instruction, 12, (4), 131-148.

Salami, S. O. (2011). Psychosocial Predictors of Adjustment among First Year College of Education Students. US-China Education Review, 8, (2), 239248.

Saniskoro, B. S. R. \& Akmal, S. Z. (2017). Peranan Penyesuaian Diri di Perguruan Tinggi terhadap Stres Akademik pada Mahasiswa Perantau di Jakarta. Jurnal Psikologi Ulayat, 4, (1), 95-106.

Sholeh, A., Sakinah., Fadhila, H.A., Nugraha, B.A., \& Widiasmara, N. (2018). Social Interaction Anxiety and Academic Adjustment among Freshmen College Student. Arts \& Education International Research Journal, 5, (2), 1-5.

Siah, P.C. \& Tan, S. H. (2015). Motivational Orientation, Perceived Stress and University Adjustment among First Year Undergraduates in Malaysia. Journal of Institutional Research South East Asia, 13, (1), 1329.

Taylor, S. E. (2015). Health psychology. (9 $9^{\text {th }}$ ed). New York: McGraw Hill Education.

Villatte, A., Marcotte, D., Potvin, A. (2017). Correlates of Depression in First-Year College Students. Canadian Journal of Higher Education, 47, 1, 114136.

Wedyaswari, M., Cahyadi, S., Susiati, E., Yuanita, R.A. (2019). Rancangan Pendampingan "4 Skills of Resillience" untuk Pengembangan Resiliensi Bidang Akademik pada Mahasiswa Bidik Misi. Jurnal Psikologi Sains dan Profesi, 3, (2), 89-98.

Wider, W., Mustapha, M., Halik, M., \& Bahari, F. (2017). Attachment as a Predictor of University Adjustment among Freshmen: Evidence form a Malaysian Public University. Malaysian Journal of Learning and Instruction, 14, (1), 111-144.

Wijanarko, E. \& Syafiq, M. (2013). Studi Fenomenologi Pengalaman Penyesuaian Diri Mahasiswa Papua di Surabaya. Jurnal Psikologi: Teori dan Terapan, 3 (2), 79-92.

Zubir, D. M. (2012). Hubungan antara psychological well-being dan college adjustment pada mahasiwa tahun pertama Universitas Indonesia. Skripsi. Fakultas Psikologi Universitas Indonesia Depok. 